\title{
Economic and Social Upgrading in Global Value Chains and Industrial Clusters: Why Governance Matters
}

\author{
Gary Gereffi · Joonkoo Lee
}

Published online: 23 September 2014

(C) Springer Science+Business Media Dordrecht 2014

\begin{abstract}
The burgeoning literature on global value chains (GVCs) has recast our understanding of how industrial clusters are shaped by their ties to the international economy, but within this context, the role played by corporate social responsibility (CSR) continues to evolve. New research in the past decade allows us to better understand how CSR is linked to industrial clusters and GVCs. With geographic production and trade patterns in many industries becoming concentrated in the global South, lead firms in GVCs have been under growing pressure to link economic and social upgrading in more integrated forms of CSR. This is leading to a confluence of "private governance" (corporate codes of conduct and monitoring), "social governance" (civil society pressure on business from labor organizations and non-governmental organizations), and "public governance" (government policies to support gains by labor groups and environmental activists). This new form of "synergistic governance" is illustrated with evidence from recent studies of GVCs and industrial clusters, as well as advances in theorizing about new patterns of governance in GVCs and clusters.
\end{abstract}

Keywords Corporate social responsibility - Global value chains · Industrial clusters · Governance $\cdot$ Economic upgrading $\cdot$ Social upgrading

G. Gereffi

Department of Sociology, Center for Globalization, Governance and Competiveness, Duke University, Durham, NC 27708, USA

e-mail: ggere@soc.duke.edu

J. Lee $(\bowtie)$

School of Business, Hanyang University, 222 Wangsimni-ro,

Seongdong-gu, Seoul 133-791, South Korea

e-mail: joonklee@hanyang.ac.kr

\section{Introduction}

Upgrading through global value chains (GVCs), or moving to higher value activities, has become important for economic development and job creation in the global economy, where competition remains intense and production has become fragmented and geographically dispersed (Cattaneo et al. 2013). Linking lead firms in GVCs with small and medium suppliers in diverse local contexts is a major business challenge in different types of industries, whether characterized by producer-driven chains like automobiles, electronics or shipbuilding for whom finding and nurturing technically capable local suppliers is a requisite of global supply chain management for manufacturers who play a leading role in determining what and how to produce (Contreras et al. 2012; Sturgeon 2003; Sturgeon et al. 2008), or in buyer-driven chains like apparel and footwear, where low cost is a major driver and retail buyers govern how the chains work (Bair and Gereffi 2001; Schmitz 2004, 2006), or fresh produce and food products, where safety and quality standards are of utmost concern for supermarkets and their customers (Humphrey and Memedovic 2006).

In order to maintain good supplier relationships in all of these settings, GVC lead firms have developed more active strategies of corporate social responsibility (CSR) (van Tulder 2009). While CSR is a multifaceted notion, it generally refers to "the responsibility of enterprises for their impacts on society" (European Commission 2011). It encompasses a wide range of efforts through which firms seek to integrate social, environmental, ethical, and human rights as well as consumer concerns into their core business practices. The goal is to maximize the benefit of shared value for a broad set of stakeholders, including owners, shareholders, and the wider society, while reducing 
potential negative impacts of corporate business practices to a minimum.

There is a growing concern, however, that economic upgrading - countries and firms moving to higher value activities in GVCs with improved technology, knowledge, and skills ${ }^{1}$ (Gereffi 2005, p. 161)-is no longer sufficient for sustainable CSR in global supply chains, given accumulating evidence and recent exposés about child labor, vulnerable workers, and abysmal working conditions in many export-oriented clusters located in developing countries (see Lund-Thomsen and Lindgreen 2014; LundThomsen and Nadvi 2010a). Improving both economic and social conditions for workers and communities linked to GVCs is a vexing development problem, and it has attracted considerable attention by researchers, policy makers, and donor communities. Indeed, this was the central theme of the "Capturing the Gains" research pro$\operatorname{gram}^{2}$ carried out over a three-year period by a large group of development scholars: Under what conditions can economic and social upgrading be combined in GVCs? Social upgrading is defined as the process of improving the rights and entitlements of workers as social actors and enhancing of the quality of their employment (Barrientos et al. 2011).

In the GVC framework, a key determinant of upgrading outcomes is the governance structure of global value chains. Governance structures are complex, and they include international as well as national regulations, and both public, private, and social forms of governance (Gereffi and Fernandez-Stark 2011; Mayer and Gereffi 2010). GVC scholars tend to focus on how external conditions and pressures, particularly by global buyers and through a variety of public and private governance processes, facilitate the diffusion of global standards and affect economic and social upgrading in developing countries (Gereffi et al. 2005); cluster scholars, by contrast, focus more on the social and cultural bonds and inter-firm learning and cluster institutions in local areas, which are considered critical for cluster upgrading (Lund-Thomsen and Pillay 2012; Schmitz 1995; Schmitz and Nadvi 1999).

Notwithstanding an ongoing dialog between the GVC and cluster literatures (Bair and Gereffi 2001; Chiarvesio et al. 2010; Humphrey and Schmitz 2002; Schmitz 2004), there is still a gap in understanding how GVCs and industrial

\footnotetext{
1 There is an extensive discussion in the GVC literature that we review below about different ways to measure economic upgrading that involve a focus on both higher value products (e.g., product upgrading, often measured with unit values of exports) and various ways of contributing to higher value-added production, including greater levels of domestic content in exports.

2 "Capturing the Gains" was funded by the UK's Department for International Development (DFID) between 2010 and 2013, and the project's publications, working papers, policy briefs, and other activities are listed on the Capturing the Gains website, http://www. capturingthegains.org/.
}

clusters interact in terms of economic and social upgrading in developing countries. This paper will review these literatures to identify the most fruitful bases for an integrated framework to better understand the governance conditions that allow economic and social upgrading in GVCs and clusters to be combined in a sustainable manner. This integrated framework has important implications for CSR, which is under pressure to move from transitory, ethical consumer-oriented public relations campaigns to "sustainable development" concerns that involve a wide range of actors across GVCs and clusters, including not only global lead firms and cluster firms but also civil society actors like non-governmental organizations (NGOs), national and local governments, labor unions, and international organizations such as the International Labor Organization (ILO), and multilateral donors like the World Bank and regional development banks (Lund-Thomsen and Lindgreen 2014).

This paper aims to contribute to the existing industrial cluster and GVC literature by highlighting the following points: (1) economic and social upgrading in developing countries are affected by the interaction of both GVC and cluster actors, and the role of social and public actors has grown as more attention is paid to social upgrading; (2) the typologies of GVC and cluster governance need to be expanded to take into account both vertical and horizontal relationships and the complex interactions-tensions, conflicts, displacement, complementarity and synergybetween public, social, and private forms of governance; and (3) depending on which types of governance and actors are involved, multiple paths for social upgrading are plausible. Six key trajectories are discussed: market, CSR, multi-stakeholder initiatives, labor, cluster, and governments. The paper focuses more on social upgrading and different pathways that can accommodate it because social upgrading has lagged behind economic upgrading in most cases. Also, social gains are not necessarily accompanied by economic gains (Barrientos et al. 2011).

The organization of our paper is as follows. The second and third sections review recent trends in the literature on industrial clusters and GVCs, respectively, and the fourth section explores how these approaches relate to economic and social upgrading. The fifth section proposes an integrated framework that shows how the increasingly diverse governance structures of GVCs and clusters are linked to different trajectories for social upgrading. The concluding section summarizes the implications for CSR of our integrated framework for industrial clusters and GVCs.

\section{Industrial Clusters and Globalization}

An industrial cluster consists of firms and related organizations within well-defined spatial boundaries engaging in 
similar sectorial activities (Porter 1998; Pyke et al. 1990). Originating in Alfred Marshall's classical concept of industrial districts, the notion was popularized by Italian small- and medium-sized enterprises (SMEs) in industrial districts that were able to successfully compete in global industries (Piore and Sabel 1984). The success was attributed to several key characteristics of industrial districts, i.e., geographic proximity and close-knit social relations, which helped to reduce transaction costs and nurture trust, and informal networks, which facilitate the flow of information, knowledge, and skills. While clusters are somewhat broader in scope than industrial districts (De Marchi and Grandinetti 2014), the two are similar in that they are diversified production structures confined to local geographic spaces.

Since the early 1990s, the role of industrial clusters and SMEs in economic development has drawn a great deal of scholarly and policy interest in the context of developing economies (Altenburg and Meyer-Stamer 1999; Ketels and Memedovic 2008; Schmitz and Nadvi 1999; see LundThomsen and Lindgreen 2014; Lund-Thomsen and Pillay 2012 for reviews). The literature suggests that clusters matter for economic upgrading because, first, the agglomeration of productive activities generates economies of scale and scope external to individual firms but internal to the cluster, and, second, it facilitates local joint actions by cluster firms and institutions to address common problems based on their interdependence. These benefits, or so-called "collective efficiency" (Schmitz 1995), are critical because SMEs in developing countries are typically too small in size and limited in resources to compete in global industries. Geographic proximity and dense social relations enable SMEs to develop a close network of suppliers and share a pool of skilled workers, information, and knowledge as well as the infrastructure necessary to collectively improve the efficiency of production activities (Sturgeon 2003). Furthermore, cluster actors engage in joint actions to address common problems (Lund-Thomsen and Pillay 2012). While cooperation among cluster firms is not easy because they often compete intensely with each other, it can be rewarding when they confront common upgrading challenges together. In organizing joint actions, the role of local cluster actors (e.g., industry associations) and institutions (e.g., trade fairs) is highlighted (Doner and Schneider 2000; Schmitz and Nadvi 1999).

In short, the industrial cluster literature highlights the importance of cluster governance operating horizontally between cluster firms and institutions in local contexts, be it learning and innovation for economic upgrading or implementing CSR measures for social upgrading. This horizontal governance can be contrasted with the vertical governance in GVCs that links global lead firms to both first-tier and local suppliers in international production networks (see below).
Cluster firms in developing economies often find themselves confronted by conflicting demands from global buyers, which seek lower labor costs while simultaneously requiring suppliers to comply with higher quality or social standards that would incur additional expenditures (Barrientos and Smith 2007; Lund-Thomsen and Pillay 2012). The fear of global buyers being "foot-loose" can keep cluster actors from making sustained investments in infrastructure or workforce development, thereby hindering local joint action. Such anxiety has grown in the face of global economic recessions (Ruwanpura and Wrigley 2011).

Clusters will have divergent responses to these challenges, depending not only on the characteristic and effectiveness of local institutions but also the form of global-local linkage and the nature of GVC governance regimes they have (Khara and Lund-Thomsen 2012; LundThomsen and Nadvi 2010a). Active upgrading efforts in industrial clusters increase the demand for high-skilled and better-paid workers as well as investment in advanced training and new skills such as product development and design (Posthuma 2008). Yet, such upgrading may increase segmentation among cluster firms between mostly larger firms that have upgraded and smaller ones that fell behind (Suresh 2010). The growing disparities can not only reduce the possibility of joint action and potential collective efficiency, but also differentiate social upgrading outcomes among the firms depending on their positions within the cluster as well as in GVCs and the end markets they are linked to (Nadvi and Barrientos 2004). In the next section, we discuss the key recent trends in GVCs that affect global-local linkage and upgrading conditions for industrial clusters in developing countries.

\section{Global Value Chains and Upgrading}

The GVC framework was created to better understand how value is created, captured, sustained, and leveraged within all types of industries. The GVC approach provides a holistic view of global industries from two vantage points: governance and upgrading. The governance of GVCs focuses mainly on lead firms and the way they organize their supply chains on a global scale, while upgrading involves the strategies used by countries, regions, firms, and other economic stakeholders to maintain or improve their positions in the global economy (Gereffi 2005). Both concepts have evolved considerably in recent years.

Governance is a centerpiece of GVC analysis. It shows how corporate power exercised by global lead firms actively shapes the distribution of profits and risks in an industry, and how this alters the upgrading prospects of firms in developed and developing economies that are 
included as well as excluded from the supply chains that constitute each industry (Gereffi and Lee 2012). The role played by lead firms is highlighted in various typologies of GVC governance. The initial distinction between producerdriven and buyer-driven commodity chains was introduced to call attention to the rise of global buyers in the 1970s and 1980s. Unlike producer-driven chains where large manufacturers control much of the production process through direct ownership, retailers and brand marketers in buyer-driven chains began to setup international sourcing networks to procure consumer goods directly from offshore suppliers, mainly in East Asia (Gereffi 1994, 1999).

However, the dichotomous categories of buyer-driven and producer-driven chains were too broad to capture the full complexity of GVC governance structures that were emerging in the world. To address this challenge, Gereffi et al. (2005) elaborated a fivefold typology of GVC governance structures, which sought both to describe and explain in a parsimonious way the main differences among various types of production networks. Between the two extremes of classic markets and hierarchies (i.e., vertical integration), three network forms of governance were identified: modular, relational, and captive (Gereffi et al. 2005; Sturgeon 2009). In these network forms of GVC governance, the lead firm exercises varying degrees of power through the coordination of suppliers without any direct ownership of the firms.

Whereas the initial distinction between producer-driven and buyer-driven commodity chains conceptualizes governance as "driving" and the more differentiated fivefold typology sees governance as "coordinating," Ponte and Sturgeon (2014) introduce a third dimension: governance as "normalizing." Following Gibbon et al. (2008), their view of normalizing draws from convention theory, and means realigning a given practice to be compatible with a standard or a norm. In all of these conceptions of GVC governance, lead firms play a crucial role by defining the terms of supply chain membership, by incorporating or excluding other actors, and by shaping how, where, when, and by whom value is added. Thus, governing in global industries requires both buyer power (e.g., setting product specifications, standards, logistics, price, etc.) as well as normative power (e.g., shaping expectations of how businesses should be organized, how quality should be assessed, or the guidelines to be followed with respect to worker rights and factory conditions) (De Marchi et al. 2014). ${ }^{3}$

\footnotetext{
3 This normative dimension is particularly important in place-based industrial clusters, where underlying phenomena like the communitarian ethos, a distinctive trait of the Marshallian industrial districts, facilitate mutual trust between people and the transfer and coproduction of knowledge (De Marchi and Grandinetti 2014).
}

Several of the recent trends in GVCs have important implications for the role of local suppliers and the likelihood of economic and social upgrading in industrial clusters (Cattaneo et al. 2013; Gereffi 2014): (1) organizational rationalization - the lead firms in these chains seek a much smaller number of big, technologically capable and strategically located suppliers (Gereffi 2014, p. 15); (2) geographic consolidation-the production hubs of these supply chains are concentrating in large emerging economies, both because of their abundant supply of workers and local firms with manufacturing expertise and also because of expanding domestic markets (Gereffi and Sturgeon 2013); and (3) a growth in South-South trade-this has surged especially since the 2008-2009 global economic recession, which dramatically slowed exports to advanced industrial markets.

Organizational rationalization tends to reinforce market dynamics and make it much harder for SMEs in industrial clusters to play a significant role in economic or social upgrading because they do not have the scale or scope to occupy the upper rungs of global supply chains. Geographic consolidation and the growth in South-South trade, on the other hand, both have the potential to support several of the trajectories of social upgrading for small firms and industrial clusters identified by Puppim de Oliveira (2008a). Geographic consolidation of production in sizeable emerging economies like China, Indonesia, Brazil, and South Africa has led to a revitalization of industrial policy (Gereffi and Sturgeon 2013), which supports the role of public governance since national governments now have greater bargaining power to pressure foreign companies for changes to benefit local interests. When combined with multi-stakeholder initiatives, including labor unions and worker activism, along with the reputational pressure placed on GVC lead firms by CSR regimes, such as corporate codes of conduct and monitoring, sustainable improvements in working conditions in developing countries become far more likely. ${ }^{4}$

The shift in global demand from the North to the South, especially after the 2008-2009 recession, and the resultant growth of South-South trade have both positive and negative consequences for industrial clusters in developing economies (Kaplinsky et al. 2011). On the positive side, lower entry barriers and less stringent product and process standards in emerging markets can facilitate the

\footnotetext{
$\overline{4}$ This may be emerging not only in the Bangladesh garment industry, with its unprecedented multi-stakeholder coalition of global retailers and brands that have pressured both the Bangladesh government and local factory owners to change legislation and business practices that have led to dangerous and degrading workplace conditions, but also in manufacturing powerhouses like China, where synergistic governance also forced changes by Foxconn and Apple in the electronics sector (Mayer 2014).
} 
participation of developing country firms in global supply chains. They can engage in higher value-added activities, such as product development and design, which they would have less chance to do in global chains. On the other hand, solely focusing on low-income markets could lock suppliers into slimmer margins and cutthroat competition.

The influence of GVCs on the upgrading of local clusters in developing countries has renewed an interest in institutions and their interaction with GVC governance. Quality conventions and standards as a governing device of GVCs play an increasing role in shaping upgrading opportunities for local clusters (Ponte and Gibbon 2005). However, most of those measures are only applied to a selected group of firms inserted into GVCs and their regular employees, while a large majority of SMEs and temporary and migrant workers, who are more vulnerable, are frequently marginalized or excluded from these benefits of the measures (Lund-Thomsen and Lindgreen 2014; Neilson and Pritchard 2010). This has led to calls for a better understanding of place-based social and institutional contexts and their interaction with diversified, co-existing local production systems as well as with multiple forms of GVC governance (Palpacuer 2008).

\section{Economic and Social Upgrading in GVCs and Industrial Clusters}

In order to more effectively link the GVC and cluster literatures to upgrading and the role of CSR, the definition of upgrading should be expanded to encompass both its economic and social dimensions. Economic upgrading is defined as a move to higher value activities in production, to improved technology, knowledge and skills, and to increased benefits or profits deriving from participation in GVCs (Gereffi 2005, p. 161). Within the GVC framework, four types of upgrading have been identified (Humphrey and Schmitz 2002):

- product upgrading, or moving into more sophisticated product lines;

- process upgrading, which transforms inputs into outputs more efficiently by reorganizing the production system or introducing superior technology;

- functional upgrading, which entails acquiring new functions (or abandoning existing functions) to increase the overall skill content of the activities; and

- chain upgrading, where firms move into new but often related industries.

Social upgrading is defined as the process of improvement in the rights and entitlements of workers as social actors and the enhancement of the quality of their employment (Barrientos et al. 2011). The concept is anchored in the ILO Decent Work framework, which encompasses employment, standards and rights at work, social protection, and social dialog (ILO 1999). Social upgrading not only includes access to better work, which might result from economic upgrading (for example, a worker that has acquired skills in one job is able to move a better job elsewhere in a GVC), but it also involves enhancing working conditions, protection and rights, thereby improving the overall well-being of workers as well as their dependents and communities. ${ }^{5}$

The social upgrading concept is related to, but more encompassing than, CSR. In recent decades, CSR initiatives by global lead firms were promoted as an effective way to improve labor conditions in GVCs that were predominantly buyer driven (Jenkins et al. 2002). Leveraging their purchasing power vis-à-vis suppliers, global buyers tried to enforce codes of conduct within their supply chains in the hope that by complying with the codes, suppliers would address social and environmental concerns in their factories (Locke et al. 2009; van Tulder 2009). Despite some progress, it has become clear that the CSR compliance model alone is woefully inadequate to fully address labor issues in global supply chains (Locke 2013; LundThomsen and Lindgreen 2014), let alone encompassing broader concerns about sustainable development. ${ }^{6}$ Also, while CSR compliance incurs significant costs to suppliers, the model generally does not allow suppliers and workers in developing countries to provide meaningful input although they are supposed to benefit from it (De Neve 2014; Dolan and Opondo 2005).

Social upgrading expands the scope of CSR by focusing not only on efforts by global companies to ameliorate labor conditions, but also other non-corporate measures initiated by NGOs and governments. It is less concerned about whether or not any specific CSR measure is effective, and shifts the question to "under what conditions" social upgrading is more likely to occur, and how that relates to economic upgrading (Barrientos et al. 2011). It suggests that there may be several distinct, yet similarly effective, ways to achieve improvement, as we discuss below.

The existing literature on clusters and GVCs often implicitly assumes that economic upgrading will automatically translate into social upgrading through better

\footnotetext{
5 Social upgrading can be subdivided into two components (Barrientos and Smith 2007; Elliott and Freeman 2003): measurable standards, which include the type of employment (regular or irregular), wage level, social protection, and working hours; and enabling rights, or less quantifiable aspects of social upgrading, such as freedom of association, the right to collective bargaining, nondiscrimination, voice, and empowerment.

${ }^{6}$ While not directly addressed in this article, we view environmental upgrading as an important corollary of economic and social upgrading in the expanded GVC research agenda we discuss here.
} 
wages and working conditions (Knorringa and Pegler 2007; Puppim de Oliveira 2008b). Case studies, however, provide a more variegated picture (Bernhardt and Milberg 2011; Nadvi and Barrientos 2004; Posthuma and Nathan 2010; Puppim de Oliveira 2008a). Social upgrading can be affected by the type of economic upgrading that is pursued. When upgrading relies mainly on the "low road" strategy of cutting labor costs, as illustrated in Indian leather clusters, the jobs created are often low-paid, informal ones with undesirable working conditions (Damodaran 2010). Labor conditions are consistently found to be better among permanent workers in the cluster context, while temporary and casual workers are excluded from social upgrading and play a 'buffering' role for the factory to remain cost competitive and flexible in terms of last minute changes in orders, resulting in segmented social upgrading even within the same cluster (Suresh 2010).

Gender bias has also been found to play an important role in industrial clusters and GVCs. Women workers tend to be engaged in insecure and low-paid work, often in temporary and seasonal employment arrangements (Barrientos and Kritzinger 2004; Mezzadri 2014). As clusters upgrade to the activities requiring a more highly skilled workforce, women and unskilled workers are often left out from social upgrading and become increasingly marginalized (Carr and Chen 2004). Indeed, the CSR measures of global buyers are often only effective within a small pocket of 'regulatory enclaves' in their own supply chains (Posthuma 2010), and smaller firms and marginal workers remain highly vulnerable (Suresh 2010).

\section{An Integrated Framework to Link Industrial Clusters to Governance and Upgrading}

To understand how different forms of governance can affect economic and social upgrading, Table 1 outlines two distinct forms of governance in industrial clusters and GVCs. Horizontal (cluster) governance refers to localitybased coordination of the economic and social relations between cluster firms as well as institutions within and beyond the cluster. Vertical (GVC) governance operates along the value chain, linking a series of buyers and suppliers in different countries, each of which adds values toward the final product. GVC scholars generally focus on the vertical, cross-national dimension of governance and cluster researchers tend to stress the role of the horizontal, place-based form of governance. However, we need to take into account both types of governance and their interaction in order to fully understand the functioning of a global industry and its consequences to economic and social upgrading in industrial clusters (Lund-Thomsen and Nadvi 2010a; Neilson and Pritchard 2009).
Table 1 Types of governance in clusters and global value chains by scope and actor

\begin{tabular}{|c|c|c|}
\hline \multirow[t]{2}{*}{ Actor } & \multicolumn{2}{|l|}{ Scope } \\
\hline & $\begin{array}{l}\text { Horizontal (cluster) } \\
\text { governance }\end{array}$ & $\begin{array}{l}\text { Vertical (GVC) } \\
\text { governance }\end{array}$ \\
\hline $\begin{array}{l}\text { Private } \\
\text { governance }\end{array}$ & $\begin{array}{l}\text { Collective efficiency } \\
\text { (e.g., industrial } \\
\text { associations, } \\
\text { cooperatives) }\end{array}$ & $\begin{array}{l}\text { GVC lead firm } \\
\text { governance (e.g., global } \\
\text { buyers' voluntary codes } \\
\text { of conduct) }\end{array}$ \\
\hline $\begin{array}{l}\text { Social } \\
\text { governance }\end{array}$ & $\begin{array}{l}\text { Local civil society } \\
\text { pressure (e.g., workers, } \\
\text { labor unions, NGOs for } \\
\text { civil, workers, and } \\
\text { environmental rights; } \\
\text { gender-equity } \\
\text { advocates) }\end{array}$ & $\begin{array}{l}\text { Global civil society } \\
\text { pressure on lead firms } \\
\text { and major suppliers } \\
\text { (e.g., Fair Labor } \\
\text { Association) and multi- } \\
\text { stakeholder initiatives } \\
\text { (e.g., Ethical Trading } \\
\text { Initiative) }\end{array}$ \\
\hline $\begin{array}{l}\text { Public } \\
\text { governance }\end{array}$ & $\begin{array}{l}\text { Local, regional, national } \\
\text { government regulations } \\
\text { (e.g., labor laws and } \\
\text { environmental } \\
\text { legislation) }\end{array}$ & $\begin{array}{l}\text { International } \\
\text { organizations (e.g., the } \\
\text { ILO, WTO) and } \\
\text { international trade } \\
\text { agreements (e.g., } \\
\text { NAFTA, AGOA) }\end{array}$ \\
\hline
\end{tabular}

Source Authors

Governance also differs by the kinds of actors involved, leading to discrete dimensions of private, public, and social governance. As more attention is paid to social upgrading, the role of public and social governance and relevant actors has grown. In clusters, private governance involves regulating economic transactions among cluster firms and with their external partners. In the cluster context, private governance is generally based on trust and mutual dependence among cluster firms and managers built around repetitive transactions and close interpersonal ties embedded in social relations within the cluster (Schmitz and Nadvi 1999). It aims to achieve collective efficiency in order for cluster firms to overcome the constraints of their smallness and share resources with one another, often mediated by institutions like cluster associations or chambers of commerce (Schmitz 1995). Joint action also could lower compliance costs for cluster firms while increasing compliance through collective monitoring and sanctions (LundThomsen and Nadvi 2010b).

In GVCs, private governance is driven by lead firms like global buyers, and often through private standards that dictate what products are to be made by whom and how (Lee et al. 2012). The key to GVC private governance lies in maximizing economic efficiency in making products whose quantity and quality are determined by lead firms in a decentralized production system. While private governance mainly pertains to economic transactions between firms in both cluster and GVC contexts, it can also involve social (and environmental) dimensions, such as working 
conditions or child labor (Khara and Lund-Thomsen 2012; Nathan and Sarkar 2011).

Public governance differs from private governance in that it is exercised by public actors, which include governments at various levels within nation-states, and supranational organizations. Public governance in the cluster context involves formal rules and regulations set by governments at local, regional, and national levels. They can facilitate or hinder social and economic upgrading directly and indirectly. National labor laws, for instance, directly impact the conditions of workers in the cluster by regulating various aspects of labor conditions and standards. Other public governance measures, such as industrial policy, trade, and investment regulations or competition policy, do not intend to address labor concerns but can indirectly affect social upgrading outcomes, while they directly impact economic upgrading. Public governance in GVCs can also be exercised through bilateral or multilateral trade agreements, such as the North American Free Trade Agreement (NAFTA) and the African Growth and Opportunity Act (AGOA). For example, social clauses are integrated into trade agreements with an aim to apply core labor standards to international trade, which can have a significant impact on smaller firms and their workers in local clusters (Polaski 2003). Relative to private standards which are voluntary, public governance, particularly government regulations, are often mandatory and have a stronger legal basis. However, it is often incomplete in design and plagued by ineffective enforcement in many developing countries.

Finally, social governance is driven by civil society actors, such as NGOs and labor unions. It provides a more explicit means of regulating workers' rights and labor conditions. These include codes of conducts initiated by NGOs, and multi-stakeholder initiatives, such as the Ethical Trade Initiative (ETI) (Barrientos and Smith 2007). In both GVCs and clusters, social governance can entail various forms of activism, such as boycotting, petitions, and protests (Selwyn 2013). This form of governance is rarely mandatory, and generally relies on the action of private firms or governments that have direct power to enforce such codes or regulations. Partly for this reason, social governance often takes a multi-stakeholder form in which public, private, and civil society actors pursue their common goals through joint action (Dolan and Opondo 2005; O'Rourke 2006). This form of joint governance, as noted above, can be more effective than private, public, or social governance alone in achieving sustainable improvements of working conditions in developing countries (Locke 2013; Mayer 2014).

However, it may not always be feasible since collective action problems often arise. Who should bear the costs of compliance with respect to labor standards has been a

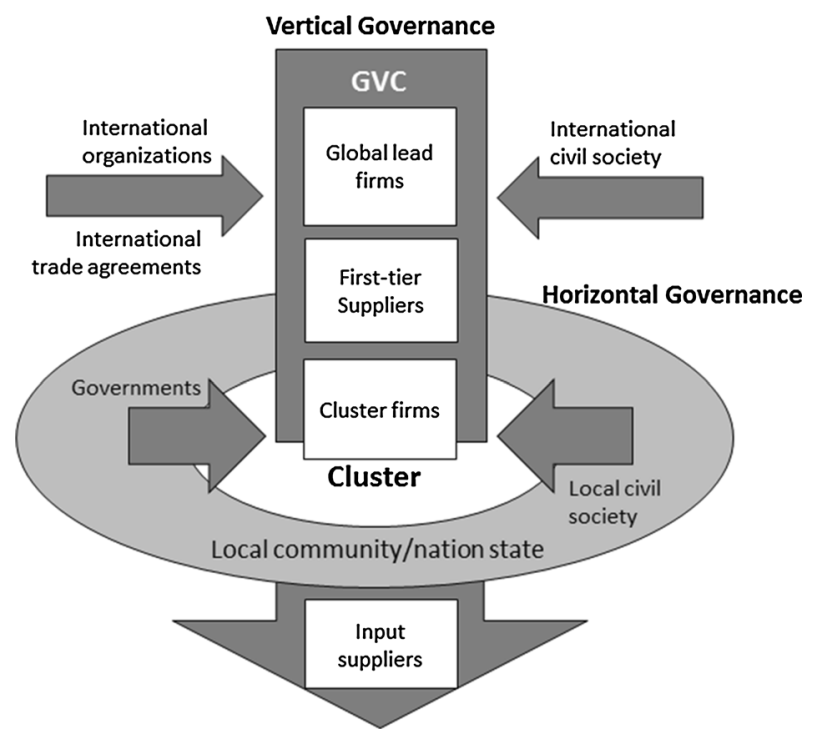

Fig. 1 The confluence of actors in GVC and cluster governance. Source Authors

contentious issue between global buyers and their suppliers, as well as among buyers, as illustrated in the recent tragic building collapse involving scores of Bangladesh garment factories (Greenhouse 2013). The literature also points to the potential for free-rider problems as some firms in industrial clusters may not want to join or pay for collective actions, yet still benefit from them (Lund-Thomsen and Pillay 2012). Different interests and views among cluster firms can affect collective action outcomes, as seen in the Jalandhar cluster where football producers and the manufacturers of other sports equipment were divided by their own interests and perspectives regarding the child labor issue (Lund-Thomsen and Nadvi 2010b).

Figure 1 illustrates the key actors in vertical and horizontal governance, and how different types of governance operate along the vertical and horizontal dimensions. As cluster firms are integrated to GVCs, they are positioned simultaneously on both dimensions, subject to governance pressure for social upgrading from vertical (GVC) or horizontal (cluster) dimensions.

GVC and cluster governance can be in conflict, creating various kinds of tensions (Neilson and Pritchard 2009). Child labor is an example. While many international NGOs, trade unions, and global buyers focus on abolishing child labor, their opposition to this practice confronts a very different viewpoint among some local firms and workers. They consider child labor as a form of job training for children who also can support their family's livelihood through work, particularly if formal schooling is not a viable option and other family members are not in a situation to get employed (Ruwanpura and Roncolato 2006).

The GVC (vertical) and cluster (horizontal) forms of governance, however, can work together to generate 
upgrading outcomes. For example, confronting allegations of labor rights abuses, Kenyan producers and industry organizations set up a local program, called the Horticultural and Ethical Business Initiative (HEBI), which formulated its own social codes and trained auditors. These efforts were supported by vertical governance actors, notably the Ethical Trading Initiative (ETI), whose members included major retail buyers like Tesco (Dolan and Opondo 2005). In the Cambodian garment sector, the Cambodian government and the Cambodian Garment Manufacturers Association (CGMA) worked with the ILO and the U.S. government to improve labor conditions in the sector, while at the same time ensuring the access of the local producers in the U.S. market (Polaski 2006).

Such complementarity is found in other forms of vertical and horizontal governance. Many corporate codes of conduct (vertical private governance) require their suppliers to abide by national laws (horizontal public governance) (Kolk and van Tulder 2004). The Better Work Program (vertical public governance), a partnership between the ILO and the International Financial Corporation (IFC), premises its "conditionality" on compliance with local labor standards (local public governance). ${ }^{7}$ In Cambodia, ILO's evaluation reports on firm compliance were used by private firms in making their sourcing decisions (Polaski 2006).

In Table 2, we identify six potential trajectories of social upgrading in industrial clusters and GVCs, building upon and expanding Puppim de Oliveira's (2008a) distinctions. Each of these six paths is driven by the key actors and mechanisms that distinguish it from the other paths. These paths are not mutually exclusive and social upgrading is typically achieved through the engagement of multiple actors (O'Rourke 2006). Yet, we seek to highlight different governance situations in which distinctive driving forces and leverage points play a critical role in advancing labor conditions and workers' rights.

(1) Market-driven path: This refers to the situation in which market demand for goods produced with high social standards forces cluster firms to improve labor conditions in their factories or farms. The key driving force for this type of upgrading is cluster firms building up their market competiveness through product and process differentiation. Such efforts can be facilitated by mutual learning of market preferences by cluster firms, which may be supported by their national, regional, or global buyers (Schmitz and Knorringa 2000). The key challenge in pursuing this trajectory is that market incentives do not always function well; the market

\footnotetext{
7 See more on the Better Work program at its website (http:// betterwork.org/global).
}

frequently fails to reward firms that provide good working conditions and punish those who are exploitative to workers (Lund-Thomsen and Lindgreen 2014; Ruwanpura and Wrigley 2011). Furthermore, market incentives may be insufficient for cluster firms to improve labor conditions if consumers they serve are unconcerned with social causes. This is likely to be the case in domestic markets, which many developing country clusters cater to (Kaplinsky and Farooki 2010), although it is still unclear to what extent Southern consumers adhere less strongly to labor concerns relative to their Northern counterparts (Knorringa 2011; Nadvi 2014). Or, market conditions may work to downgrade labor conditions. For example, the changing international demand for footballs involved a major reorganization of the Jalandhar football cluster in India, which had detrimental impacts on its competitiveness and the ability of women to participate in the workforce (Khara and Lund-Thomsen 2012).

(2) CSR-driven path: Cluster firms can improve the treatment of their workers to comply with global buyers' social codes of conduct (Lund-Thomsen and Nadvi 2010a, b; Puppim de Oliveira 2008a). This path is driven by global buyers' explicit commitment to CSR, and corresponds to what is called the 'compliance' paradigm (Locke et al. 2009). While leading global brands need to avoid reputational damage that might be caused by the public disclosure of labor wrongdoings in their supply chains, cluster firms linked to the chains have the incentive to comply with the buyers' codes of conduct if it ensures access to global markets and differentiates them from other suppliers. Severe or repeated instances of non-compliance or violations of the codes could jeopardize such access (Lund-Thomsen and Nadvi 2010b). Notwithstanding some success in certain areas of social upgrading, such as forced labor and health and safety, the compliance model confronts considerable limitations in further advancing social upgrading (Locke 2013). The demands of the buyers often seem contradictory-e.g., they are forced to squeeze costs while simultaneously complying with the buyers' labor codes that provide little or no support for compliance costs (Barrientos 2013). Furthermore, many clusters in developing countries serve the needs of domestic markets, or are linked to 'less visible' chains. In such clusters, CSR pressures may be weak and not adequately address the specific needs of the more disadvantaged actors (Neilson and Pritchard 2010). Compliance pressures may come not only from vertical governance but also from diverse sets of local actors, including 
national media and local NGOs (Lund-Thomsen and Nadvi 2010b), opening up other possible upgrading paths.

(3) Multi-stakeholder path: The key momentum of this path comes from a multi-stakeholder initiative (MSI) to improve working conditions in SMEs in developing countries in a specific sector (e.g., Clean Cloth Campaign in apparel) or across sectors (e.g., SA8000, the ETI) (Barrientos and Smith 2007; O'Rourke 2006). This model is distinctive from the CSR-driven compliance model. First, it is based on the cooperation of multiple (private and non-private) stakeholders, including national governments, cluster institutions, and local firms. Diversity and multivocality are the key to the model (Dolan and Opondo 2005). Second, it combines compliance-monitoring with capability-building so that clusters can learn how to address labor issues on their own (Locke et al. 2009). The key driver is a broad-based coalition of various types of global and local actors-global lead brands, international and local NGOs, trade unions, cluster firms and industry associations - that cooperate in standard-setting, monitoring and sanctions as well as capabilitybuilding. While the MSI model uses standardized codes of conduct and third-party accreditation (O'Rourke 2006), local industries and clusters can generate collective responses, such as their own base codes and methodologies for audits, as Kenyan cut flower producers did (Dolan and Opondo 2005). While local cluster firms and industry associations generally play a prominent role in 'less visible' chains, they can significantly contribute to social upgrading even in a 'highly visible' chain by organizing collective actions and enhancing the effectiveness and embeddedness of such activities in the local context (Lund-Thomsen and Nadvi 2010b). Several challenges, however, are cited for the MSI model. For instance, stakeholders have different degrees of power, which affects how individual initiatives unfold (Dolan and Opondo 2005). Also, the participation of Southern actors in MSI generally remains constrained (O'Rourke 2006). Finally, capability-building may be limited to a few large cluster firms, not being spread across and beyond the cluster, as more hazardous jobs shift further down the supply chains or into the informal sectors (Lund-Thomsen and Lindgreen 2014).

(4) Labor-centered path: In some cases, the role of workers and labor unions is at least as significant as that of global buyers in promoting upgrading. Workers have increasingly been asserting their rights even in the places, like China, where labor unions have traditionally been less effective (Gallagher 2014). The advocates of this path criticize both CSR and MSI models for regarding workers as a passive subject with little agency (Carswell and De Neve 2013; De Neve 2014). Indeed, workers and trade unions are often active change agents in improving their own social conditions. Workers themselves can be the best monitors on the ground (O'Rourke 2006). And in a tightly scheduled production system, workers' power to disrupt the supply chains with strikes or threats to do so can be critical in their bargaining with employers. This is also the case for skilled workers where quality is emphasized in production, as in the horticulture sectors in Brazil and Sub-Saharan Africa (Barrientos and Visser 2012; Selwyn 2013). One of the challenges for the labor-driven path is that in a segmented workplace, upgrading for one group of workers, for example, regular employees, often comes at the expense of other groups of workers, like women, migrant, casual, or temporary workers as well as those in the informal sectors. Employers can try to make up for their concession to one group with gains from others and use the latter as a buffer for their flexibility (Posthuma 2010; Selwyn 2013).

(5) Cluster-driven path: This bottom-up path is initiated by cluster firms to improve working conditions within the cluster. Similar to workers, cluster actors tend to be portrayed as "standard-takers" rather than "standard-setters." However, implementing externally driven labor codes often involves various kinds of tensions and conflicts with local institutions and practices (Lund-Thomsen and Nadvi 2010a). Cluster-based initiatives, by contrast, take into account local contexts and perspectives. They also consider potential economic gains for cluster firms, which are often not the central concern in global buyers' CSR initiatives. The key mechanism of this model is cluster-based collective actions toward the improvement of labor conditions, facilitated by trust and mutual dependence between closely knit firms. Cluster institutions, such as business associations, chambers of commerce and cooperatives, play a key role by providing training and information on quality and social standards in external markets (Doner and Schneider 2000; Puppim de Oliveira 2008b). Even in the cases where cluster initiatives are prompted by pressures from global lead firms or international NGOs, local governance at the cluster level can play an important role by facilitating the effective implementation of collective actions (Lund-Thomsen and Nadvi 2010b). These collective actions can lower compliance costs, promote the local ownership of 
social codes, improve the effectiveness of compliance-monitoring, and embed social goals in cluster norms and practices. The potential weakness of the model, however, is that local initiatives can be delayed or downscaled without sustained external pressures from global brands and independent scrutiny from NGOs, as often the case in 'less visible' chains (Lund-Thomsen and Nadvi 2010b). For example, locally controlled child labor monitoring in Jalandhar, Pakistan was found weaker compared to a similar system in Sialkot, where well-known global brands are present (Lund-Thomsen and Nadvi 2010a).

(6) Public governance path: Public regulations are important because they can make the most farreaching impact on improving labor conditions involving all the suppliers under their jurisdiction, regardless of whether they are inside or out of a GVC or a cluster (Mayer and Gereffi 2010). The role of the state is particularly important in "enforcing the law" (Puppim de Oliveira 2008a), preventing defections by individual firms, and resolving collective action problems among various stakeholders (Amengual 2010). State power comes from various levels, including government ministries (Tewari and Pillai 2005) and Supreme Courts (Crow and Batz 2006) at a national level to labor inspectors at a local level (Coslovsky 2014). The state's actions are prompted by workers' grievances and public discomfort with undesirable labor conditions as well as transnational campaigns demanding a stricter enforcement of labor laws and policing of labor abuses. Scholars have recently suggested that the state can go beyond its traditional, deterrence-based regulations to take more innovative and experimental approaches by collaborating with private and civil actors, providing incentives such as technical assistance, supporting local capability-building initiatives, and closing off "low-road" options ${ }^{8}$ (Locke 2013). The question, however, is whether national or local governments have the will to act to promote social upgrading in the face of business pressures not to drive away foreign investors. It is also unclear how much the state is capable of mediating the

\footnotetext{
${ }^{8}$ In one such example in Brazil, labor inspectors not only enforced the labor law but also actively engaged in devising local arrangements such as employers' consortia and prompted producers to make their work practices safer (Coslovsky 2014, p. 210). Similarly, labor inspectors in the Dominican Republic, in addition to their conventional role of law enforcement, took a proactive approach to labor regulation and engaged in educating workers about their rights and reconciling disputes between employers and workers (Amengual 2010).
}

competing interests of different stakeholders. Despite some evidence of a proactive role of the state, it is unknown whether such models are applicable to a wide range of countries, different levels of government, and all sectors.

Table 2 summarizes key drivers, mechanisms, and actors involved in each of these social upgrading paths. In reality, social upgrading tends to be achieved through the engagement of multiple actors with distinctive capabilities and limitations (O'Rourke 2006). For example, global standards are rarely implemented in a cluster without interacting with local contexts, creating various kinds of conflicts and tensions with existing local norms and institutions (Neilson and Pritchard 2009). Consequently, what actually emerges is a form of governance "co-produced" by global and local, public, social and private actors (LundThomsen and Nadvi 2010a).

When different types of governance coexist and interact, one possible outcome is displacement-i.e., one type of governance can pre-empt, displace, or crowd out other forms. Private governance like CSR, for instance, may replace public governance and weaken other forms of governance, such as local labor institutions or labor unions (Justice 2005; O'Rourke 2003). In criticizing fair and ethical trade initiatives for their limited scope, Neilson and Pritchard (2010) argue that the initiatives tend to "supplant traditional regulatory formations anchored in the national state" (p. 1847). Bartley (2005) not only finds some empirical support for the displacement hypothesis in his study of the apparel sector, but also highlights that the rise of private labor regulations was highly contested and, as a result, the outcome is more complex than simple displacement.

Another possibility is that different forms of governance can complement each other (Amengual 2010; Polaski 2006) and, in some cases, lead to a 'hybrid system of regulation' (Amengual 2010), or 'synergistic governance' (Mayer 2014). Private and public governance can have comparative strengths and weaknesses that make them complementary (Rodríguez-Garavito 2005). ${ }^{9}$ Private auditing, for example, did not replace but rather complemented state regulations in the Dominican Republic's export processing zones by freeing up scarce government resources for monitoring and directing them to 'less visible' firms in the informal sector (Amengual 2010). Furthermore, scholars are recently beginning to identify sets of conditions in GVCs and industrial clusters under which economic and social upgrading in global supply chains can come together and be mutually reinforcing (Barrientos

\footnotetext{
9 As Coslovsky and Locke (2013) point out, such complementarity may not require explicit communication and coordination between private and public governance actors to make each other's actors effective (see also Amengual 2010).
} 
Table 2 Key drivers, mechanisms, and actors of social upgrading

Source Authors

\begin{tabular}{|c|c|c|c|}
\hline & Key drivers & Main mechanisms & Major actors \\
\hline $\begin{array}{l}\text { Market- } \\
\text { driven path }\end{array}$ & Market competitiveness & $\begin{array}{l}\text { Market supply and } \\
\text { demand }\end{array}$ & $\begin{array}{l}\text { Buyers; consumers; } \\
\text { suppliers }\end{array}$ \\
\hline $\begin{array}{l}\text { CSR-driven } \\
\text { path }\end{array}$ & $\begin{array}{l}\text { Global buyer's reputation and } \\
\text { purchasing power }\end{array}$ & $\begin{array}{l}\text { Compliance to buyers } \\
\text { codes; social audits }\end{array}$ & Global buyers \\
\hline $\begin{array}{l}\text { Multi- } \\
\text { stakeholder } \\
\text { path }\end{array}$ & $\begin{array}{l}\text { A broad-based coalition for } \\
\text { standard-setting, monitoring, } \\
\text { capability-building and } \\
\text { sanctions }\end{array}$ & $\begin{array}{l}\text { Multiple, standardized, } \\
\text { social standards; } \\
\text { capability-building and } \\
\text { cooperation }\end{array}$ & $\begin{array}{l}\text { International NGOs; } \\
\text { global buyers; local } \\
\text { actors }\end{array}$ \\
\hline $\begin{array}{l}\text { Labor- } \\
\text { centered } \\
\text { path }\end{array}$ & $\begin{array}{l}\text { Workers' grievances; exercise of } \\
\text { bargaining power }\end{array}$ & $\begin{array}{l}\text { Collective bargaining; } \\
\text { strikes; sabotages }\end{array}$ & Workers; labor unions \\
\hline $\begin{array}{l}\text { Cluster- } \\
\text { centered } \\
\text { path }\end{array}$ & $\begin{array}{l}\text { External CSR pressure; } \\
\text { collective efficiency }\end{array}$ & $\begin{array}{l}\text { Collective standard- } \\
\text { setting, } \\
\text { implementation, } \\
\text { support }\end{array}$ & $\begin{array}{l}\text { Cluster firms; industrial } \\
\text { associations; } \\
\text { cooperatives }\end{array}$ \\
\hline $\begin{array}{l}\text { Public } \\
\text { governance } \\
\text { path }\end{array}$ & $\begin{array}{l}\text { Public pressure; experimentalist } \\
\text { approach to improve workers } \\
\text { well-being }\end{array}$ & $\begin{array}{l}\text { Strong labor law; law } \\
\text { enforcement }\end{array}$ & $\begin{array}{l}\text { National, regional, and } \\
\text { local governments }\end{array}$ \\
\hline
\end{tabular}

et al. 2011; Mayer and Gereffi 2010; Puppim de Oliveira 2008b).

Although private governance alone may not bring about sustainable changes in labor or environmental conditions, private voluntary standards appear to be most effective when they are layered on and blended with public mandatory regulations (Locke 2013). Like corporate codes of conduct, CSR regimes may also have the greatest chance to succeed if they are combined with favorable market conditions, multi-stakeholder coalitions, government willingness and capacity to act, and sustained pressure from organized workers and other civic activists.

\section{Conclusions}

Global value chains and industrial clusters have been changing in significant ways in recent years. While the researchers who study these phenomena tend to focus on different levels of analysis-global and local, respectively - there is a need for more integrated frameworks that show how GVCs and clusters are connected through a variety of globalization processes, such as those outlined in this paper. The linking of GVCs and clusters also offers some constructive recommendations for CSR, since GVC lead firms are under pressure to move beyond narrow costbased models of competition in order to promote more sustainable development. This requires a shift from inactive or reactive CSR strategies, in which supply chain relationships are considered to be a liability of supply chain management, to more active and proactive CSR strategies, which highlight broader societal responsibilities related to local suppliers and communities (van Tulder 2009).
This article proposes several building blocks for a more integrated CSR framework. First, economic and social upgrading should be linked in our GVC and cluster models, and we need to pursue research agendas that seek to identify the conditions under which economic and social upgrading can be mutually supportive (Barrientos et al. 2011; 2012; and the Capturing the Gains project highlighted in endnote 2). Second, we need to expand and integrate our typologies of GVC and cluster governance, which tend to focus on vertical and horizontal relationships, respectively, in order to take account of the different actors that are linked to private, public, and social forms of governance. Third, while we have highlighted six different pathways for social upgrading, we have suggested the importance of "synergistic governance" as a way to advance more comprehensive and sustainable forms of upgrading, both economically and socially. Synergistic governance is not easy to achieve, but it offers a promising pathway to bringing together corporate, governmental, and civil society actors in a global setting to achieve joint objectives, where active collaboration among GVC and industrial cluster actors is required in order to simultaneously achieve economic and social gains.

Future research should make more explicit under what conditions complementary and synergistic forms of governance (or alliances among different governance actors) are likely to emerge, and what enables joint forms of governance to become institutionalized in the cluster (Amengual 2010; Mayer and Gereffi 2010). We also need to know how different paths or trajectories could accelerate social and economic upgrading in developing country clusters. To answer these questions, research projects that more explicitly link the cluster and GVC paradigms are needed. 
Acknowledgments The authors would like to thank Peter LundThomsen and two anonymous reviewers for valuable feedback on earlier versions of this paper. Lee's work was supported by the research fund of Hanyang University (HY-2012-2430). All errors of fact and interpretation are our responsibility.

\section{References}

Altenburg, T., \& Meyer-Stamer, J. (1999). How to promote clusters: Policy experiences from Latin America. World Development, 27(9), 1693-1713.

Amengual, M. (2010). Complementary labor regulation: The uncoordinated combination of state and private regulators in the Dominican Republic. World Development, 38(3), 405-414.

Bair, J., \& Gereffi, G. (2001). Local clusters in global chains: The causes and consequences of export dynamism in Torreon's blue jeans industry. World Development, 29(11), 1885-1903.

Barrientos, S. (2013). Corporate purchasing practices in global production networks: A socially contested terrain. Geoforum, $44,44-51$.

Barrientos, S., Gereffi, G., \& Nathan, D. (2012). Economic and social upgrading in global value chains: Emerging trends and pressures. Capturing the Gains Summit Briefing, University of Manchester. Retrieved June 9, 2014 from http://www.capturingthegains.org/ pdf/CTG-GVC.pdf.

Barrientos, S., Gereffi, G., \& Rossi, A. (2011). Economic and social upgrading in global production networks: A new paradigm for a changing world. International Labour Review, 150(3-4), 319-340.

Barrientos, S., \& Kritzinger, A. (2004). Squaring the circle: Global production and the informalization of work in South African fruit exports. Journal of International Development, 16(1), 81-92.

Barrientos, S., \& Smith, S. (2007). Do workers benefit from ethical trade? Assessing codes of labour practice in global production systems. Third World Quarterly, 28(4), 713-729.

Barrientos, S., \& Visser, M. (2012). South African horticulture: Opportunities and challenges for economic and social upgrading in value chains. Capturing the Gains Working Paper 2012/12, University of Manchester. Retrieved June 9, 2014 from http://www.capturingth egains.org/publications/workingpapers/wp_201212.htm.

Bartley, T. (2005). Corporate accountability and the privatization of labor standards: Struggles over codes of conduct in the apparel industry. Research in Political Sociology, 14, 211-244.

Bernhardt, T., \& Milberg, W. (2011). Economic and social upgrading in global value chains: Analysis of horticulture, apparel, tourism and mobile telephones. Capturing the Gains Working Paper 2011/06. Retrieved May 19, 2014 from http://www.capturingth egains.org/publications/workingpapers/wp_201106.htm.

Carr, M., \& Chen, M. (2004). Globalization, social exclusion and work: With special reference to informal employment and gender. International Labour Office, Geneva. Retrieved November 20, 2013 from http://www.ilo.org/dyn/dwresources/docs/ 625/F1146925582/gender\%20and\%20globalisation.pdf.

Carswell, G., \& De Neve, G. (2013). Labouring for global markets: Conceptualising labour agency in global production networks. Geoforum, 44, 62-70.

Cattaneo, O., Gereffi, G., Miroudot, S., \& Taglioni, D. (2013). Joining, upgrading and being competitive in global value chains: A strategic framework. World Bank Policy Research Working Paper 6406, The World Bank, Washington DC. Retrieved May 10, 2014 from http://www-wds.worldbank.org/external/default/ WDSContentServer/IW3P/IB/2013/04/09/000158349_20130409 182129/Rendered/PDF/wps6406.pdf.
Chiarvesio, M., Di Maria, E., \& Micelli, S. (2010). Global value chains and open networks: The case of Italian industrial districts. European Planning Studies, 18(3), 333-350.

Contreras, O. F., Carrillo, J., \& Alonso, J. (2012). Local entrepreneurship within global value chains: A case study in the Mexican automotive industry. World Development, 40(5), 1013-1023.

Coslovsky, S. V. (2014). Flying under the radar? The state and the enforcement of labour laws in Brazil. Oxford Development Studies, 42(2), 190-216.

Coslovsky, S. V., \& Locke, R. (2013). Parallel paths to enforcement: Private compliance, public regulation, and labor standards in the Brazilian sugar sector. Politics \& Society, 41(4), 497-526.

Crow, M., \& Batz, M. B. (2006). Clean and competitive? Small-scale bleachers and dyers in Tirupur, India. In A. Blackman (Ed.), Small firms and the environment in developing countriescollective action and collective impacts (pp. 147-170). Washington, DC: REF Press.

Damodaran, S. (2010). Upgradation or flexible casualization? Exploring the dynamics of global value chain incorporation in the Indian leather industry. In A. Posthuma \& D. Nathan (Eds.), Labour in global production networks in India (pp. 231-250). New Delhi; New York: Oxford University Press.

De Marchi, V., \& Grandinetti, R. (2014). Industrial districts and the collapse of the Marshallian model: Looking at the Italian experience. Competition \& Change, 18(1), 70-87.

De Marchi, V., Di Maria, E., \& Ponte, S. (2014). Multinational firms and the management of global networks: Insights from global value chain studies. In T. Pedersen, M. Venzin, T. M. Devinney \& L. Tihanyi (Eds.), Orchestration of the global network organization (pp. 463-486). Bingley: Emerald Group Publishing Limited.

De Neve, G. (2014). Fordism, flexible specialisation and CSR: How Indian garment workers critique neoliberal labour regimes. Ethnography, 15(2), 184-207.

Dolan, C. S., \& Opondo, M. (2005). Seeking common ground-multistakeholer processes in Kenya's cut flower industry. Journal of Corporate Citizenship, 18, 87-98.

Doner, R. F., \& Schneider, B. R. (2000). Business associations and economic development: Why some associations contribute more than others. Business and Politics, 2(3), 261-288.

Elliott, K. A., \& Freeman, R. B. (2003). The role global labor standards could play in addressing basic needs. In J. Heymann (Ed.), Global inequalities at work (pp. 299-327). New York: Oxford University Press.

European Commission. (2011). A renewed EU strategy 2011-2014 for corporate social responsibility. European Commission, Brussels. Retrieved May 10, 2014 from http://eur-lex.europa.eu/LexUri Serv/LexUriServ.do?uri=COM:2011:0681:FIN:EN:PDF.

Gallagher, M. E. (2014). China's workers movement \& the end of the rapid-growth era. Daedalus, 143(2), 81-95.

Gereffi, G. (1994). The organization of buyer-driven global commodity chains: How US retailers shape overseas production networks. In G. Gereffi \& M. Korzeniewicz (Eds.), Commodity chains and global capitalism (pp. 95-122). Westport, CT: Greenwood Press.

Gereffi, G. (1999). International trade and industrial upgrading in the apparel commodity chains. Journal of International Economics, $48(1), 37-70$.

Gereffi, G. (2005). The global economy: Organization, governance, and development. In N. J. Smelser \& R. Swedberg (Eds.), The handbook of economic sociology (2nd ed., pp. 160-182). Princeton, NJ: Princeton University Press.

Gereffi, G. (2014). Global value chains in a post-Washington consensus world. Review of International Political Economy, 21(1), 9-37.

Gereffi, G., \& Fernandez-Stark, K. (2011). Global value chain analysis: A primer. Center on Globalization, Governance \& 
Competitiveness, Durham, NC. Retrieved December 4, 2013 from http://www.cggc.duke.edu/pdfs/2011-05-31_GVC_analy sis_a_primer.pdf.

Gereffi, G., Humphrey, J., \& Sturgeon, T. (2005). The governance of global value chains. Review of International Political Economy, 12(1), 78-104.

Gereffi, G., \& Lee, J. (2012). Why the world suddenly cares about global supply chains. Journal of Supply Chain Management, 48(3), 24-32.

Gereffi, G., \& Sturgeon, T. J. (2013). Global value chain-oriented industrial policy: The role of emerging economies. In D. K. Elms $\&$ P. Low (Eds.), Global value chains in a changing world (pp. 329-360). Geneva: World Trade Organization, Fung Global Institute and Temasek Foundation Centre for Trade \& Negotiations.

Gibbon, P., Bair, J., \& Ponte, S. (2008). Governing global value chains: An introduction. Economy and Society, 37(3), 315-338.

Greenhouse, S. (2013). U.S. Retailers decline to aid factory victims in Bangladesh. New York Times, November 23. Retrieved July 19, 2014 from http://www.nytimes.com/2013/11/23/business/interna tional/us-retailers-decline-to-aid-factory-victims-in-bangladesh. html.

Humphrey, J., \& Memedovic, O. (2006). Global value chains in the agrifood sector. United Nations Industrial Development Organization Working Paper, Vienna. Retrieved March 11, 2014 from http://www.unido.org/fileadmin/user_media/Publications/Pub_ free/Global_value_chains_in_the_agrifood_sector.pdf.

Humphrey, J., \& Schmitz, H. (2002). How does insertion in global value chains affect upgrading in industrial clusters? Regional Studies, 36(9), 1017-1027.

ILO. (1999). Decent work: Report of the director-general to the 89th session of the international labour conference. International Labor Organization, Geneva. Retrieved May 10, 2014 from http://www. ilo.org/public/libdoc/ilo/P/09605/09605(1999-87).pdf.

Jenkins, R. O., Pearson, R., \& Seyfang, G. (2002). Corporate responsibility and labour rights: Codes of conduct in the global economy. London: Earthscan.

Justice, D. W. (2005). The corporate social responsibility concept and phenomenon: Challenges and opportunities for trade unionists. Presented at the ITC-ILO/ACTRAV Course A3-50909: Trade Union Training for Global Union Federations in Asia and the Pacific Region on Globalization, Workers' Rights and Corporate Social Responsibility (CSR), Kuala Lumpur, Malaysia.

Kaplinsky, R., \& Farooki, M. (2010). Global value chains, the crisis, and the shift of markets from north to south. In O. Cattaneo, G. Gereffi, \& C. Staritz (Eds.), Global value chains in a postcrisis world: A development perspective (pp. 125-153). Washington, DC: World Bank.

Kaplinsky, R., Terheggen, A., \& Tijaja, J. (2011). China as a final market: The Gabon timber and Thai cassava value chains. World Development, 39(7), 1177-1190.

Ketels, C. H., \& Memedovic, O. (2008). From clusters to clusterbased economic development. International Journal of Technological Learning, Innovation and Development, 1(3), 375-392.

Khara, N., \& Lund-Thomsen, P. (2012). Value chain restructuring, work organization and labour outcomes in football manufacturing in India. Competition \& Change, 16(4), 261-280.

Knorringa, P. (2011). Value chain responsibility in the global south. In S. M. Murshed, P. Goulart, \& L. Serino (Eds.), South-South globalization: Challenges and opportunities for development (pp. 194-208). New York: Routledge.

Knorringa, P., \& Pegler, L. (2007). Integrating labour issues in global value chains analysis: Exploring implications for labour research and unions. In V. Schmidt (Ed.), Trade union responses to globalisation: A review by the global unions research network (pp. 35-51). Geneva: International Labour Organization.

Kolk, A., \& van Tulder, R. (2004). Ethics in international business: Multinational approaches to child labor. Journal of World Business, 39(1), 49-60.

Lee, J., Gereffi, G., \& Beauvais, J. (2012). Global value chains and agrifood standards: Challenges and possibilities for smallholders in developing countries. Proceedings of the National Academy of Sciences of the United States of America, 191(31), 12326-12331.

Locke, R. M. (2013). The promise and limits of private power: Promoting labor standards in a global economy. Cambridge; New York: Cambridge University Press.

Locke, R., Amengual, M., \& Mangla, A. (2009). Virtue out of necessity? Compliance, commitment, and the improvement of labor conditions in global supply chains. Politics \& Society, 37(3), 319-351.

Lund-Thomsen, P., \& Lindgreen, A. (2014). Corporate social responsibility in global value chains: Where are we now and where are we going? Journal of Business Ethics, 123(1), 11-22.

Lund-Thomsen, P., \& Nadvi, K. (2010a). Clusters, chains and compliance: Corporate social responsibility and governance in football manufacturing in South Asia. Journal of Business Ethics, 93(2), 201-222.

Lund-Thomsen, P., \& Nadvi, K. (2010b). Global value chains, local collective action and corporate social responsibility: A review of empirical evidence. Business Strategy and the Environment, 19(1), 1-13.

Lund-Thomsen, P., \& Pillay, R. G. (2012). CSR in industrial clusters: An overview of the literature. Corporate Governance, 12(4), $568-578$.

Mayer, F. (2014). Leveraging private governance for public purpose: Business, civil society and the state in labour regulation. In A. Payne \& N. Philips (Eds.), Handbook on the international political economy of governance (pp. 344-360). Cheltenham, UK: Edward Elgar.

Mayer, F., \& Gereffi, G. (2010). Regulation and economic globalization: Prospects and limits of private governance. Business and Politics, 12(3), 1-25.

Mezzadri, A. (2014). Indian garment clusters and CSR norms: Incompatible agendas at the bottom of the garment commodity chain. Oxford Development Studies, 42(2), 238-258.

Nadvi, K. (2014). 'Rising powers' and labour and environmental standards. Oxford Development Studies, 42(2), 137-150.

Nadvi, K., \& Barrientos, S. (2004). Industrial clusters and poverty reduction: Towards a methodology for poverty and social impact assessment of cluster development initiatives. United Nations Industrial Development Organization, Vienna. Retrieved December 10, 2013 from http://www.unido.org/fileadmin/user_media/ Services/PSD/Clusters_and_Networks/publications/industrial Clustersandpoverty_NADVI.pdf.

Nathan, D., \& Sarkar, S. (2011). Blood on your mobile phone? Capturing the gains for artisanal miners, poor workers and women. Capturing the Gains Briefing Note, No. 2. Retrieved June 9, 2014 from http:// www.capturingthegains.org/publications/briefingnotes/bp_02. htm.

Neilson, J., \& Pritchard, B. (2009). Value chain struggles: Institutions and governance in the plantation districts of South India. Malden, MA.: Wiley.

Neilson, J., \& Pritchard, B. (2010). Fairness and ethicality in their place: The regional dynamics of fair trade and ethical sourcing agendas in the plantation districts of South India. Environment and Planning A, 42(8), 1833-1851.

O'Rourke, D. (2003). Outsourcing regulation: Analyzing nongovernmental systems of labor standards and monitoring. Policy Studies Journal, 31(1), 1-29. 
O'Rourke, D. (2006). Multi-stakeholder regulation: Privatizing or socializing global labor standards? World Development, 34(5), 899-918.

Palpacuer, F. (2008). Bringing the social context back in: Governance and wealth distribution in global commodity chains. Economy and Society, 37(3), 393-419.

Piore, M. J., \& Sabel, C. F. (1984). The second industrial divide. New York: Basic Books.

Polaski, S. (2003). Protecting labor rights through trade agreements: An analytical guide. UC Davis Journal of International Law and Policy, 10(1), 13-25.

Polaski, S. (2006). Combining global and local forces: The case of labor rights in Cambodia. World Development, 34(5), 919-932.

Ponte, S., \& Gibbon, P. (2005). Quality standards, conventions and the governance of global value chains. Economy and Society, 34(1), 1-31.

Ponte, S., \& Sturgeon, T. (2014). Explaining governance in global value chains: A modular theory-building effort. Review of International Political Economy, 21(1), 195-223.

Porter, M. E. (1998). Clusters and the new economics of competition. Harvard Business Review, 76(6), 77-90.

Posthuma, A. (2008). Seeking the high road to Jepara: Challenges for economic and social upgrading in Indonesian wood furniture clusters. In J. A. Puppim de Oliveira (Ed.), Upgrading clusters and small enterprises in developing countries: Environmental, labor, innovation and social issues (pp. 23-43). Burlington, VT: Ashgate.

Posthuma, A. (2010). Beyond 'regulatory enclaves': Challenges and opportunities to promote decent work in global production networks. In A. Posthuma \& D. Nathan (Eds.), Labour in global production networks in India (pp. 57-80). New York: Oxford University Press.

Posthuma, A., \& Nathan, D. (Eds.). (2010). Labour in global production networks in India. New York: Oxford University Press.

Puppim de Oliveira, J. A. (2008a). Introduction: Social upgrading among small firms and clusters. In J. A. Puppim de Oliveira (Ed.), Upgrading clusters and small enterprises in developing countries: Environmental, labor, innovation and social issues (pp. 1-21). Burlington, VT: Ashgate.

Puppim de Oliveira, J. A. (Ed.). (2008b). Upgrading clusters and small enterprises in developing countries: Environmental, labor, innovation and social issues. Burlington, VT: Ashgate.

Pyke, F. S., Becattini, G., \& Sengenberger, W. (Eds.). (1990). Industrial districts and inter-firm co-operation in Italy. Geneva: International Institute for Labour Studies.
Rodríguez-Garavito, C. A. (2005). Global governance and labor rights: Codes of conduct and anti-sweatshop struggles in global apparel factories in Mexico and Guatemala. Politics \& Society, 33(2), 203-333.

Ruwanpura, K. N., \& Roncolato, L. (2006). Child rights: An enabling or disabling right? The nexus between child labor and poverty in Bangladesh. Journal of Developing Societies, 22(4), 359-378.

Ruwanpura, K. N., \& Wrigley, N. (2011). The costs of compliance? Views of Sri Lankan apparel manufacturers in times of global economic crisis. Journal of Economic Geography, 11(6), 1031-1049.

Schmitz, H. (1995). Collective efficiency: Growth path for smallscale industry. Journal of Development Studies, 31(4), 529-566.

Schmitz, H. (2004). Local enterprises in the global economy: Issues of governance and upgrading. Cheltenham, UK: Edward Elgar.

Schmitz, H. (2006). Learning and earning in global garment and footwear chains. European Journal of Development Research, 18(4), 546-571.

Schmitz, H., \& Knorringa, P. (2000). Learning from global buyers. Journal of Development Studies, 37(2), 177-205.

Schmitz, H., \& Nadvi, K. (1999). Clustering and industrialization: Introduction. World Development, 27(9), 1503-1514.

Selwyn, B. (2013). Social upgrading and labour in global production networks: A critique and an alternative conception. Competition \& Change, 17(1), 75-90.

Sturgeon, T. J. (2003). What really goes on in Silicon Valley? Spatial clustering and dispersal in modular production networks. Journal of Economic Geography, 3(2), 199-225.

Sturgeon, T. J. (2009). From commodity chains to value chains: Interdisciplinary theory building in an age of globalization. In J. Bair (Ed.), Frontiers of commodity chain research (pp. 110-135). Stanford, California: Stanford University Press.

Sturgeon, T. J., Van Biesebroeck, J., \& Gereffi, G. (2008). Value chains, networks and clusters: Reframing the global automotive industry. Journal of Economic Geography, 8(3), 297-321.

Suresh, T. G. (2010). Cost cutting pressures and labour relations in Tamil Nadu's automobile components supply chain. In A. Posthuma \& D. Nathan (Eds.), Labour in global production networks in India (pp. 251-271). New York: Oxford University Press.

Tewari, M., \& Pillai, P. (2005). Global standards and the dynamics of environmental compliance in India's leather industry. Oxford Development Studies, 33(2), 245-267.

van Tulder, R. (2009). Chains for change. Position paper for the Third Max Havelaar lecture. Retrieved January 6, 2014 from http:// www.maxhavelaarlecture.org/downloads/max_havelaar_lec tures_2009_booklet.pdf. 